\title{
Anatomic compatibility of pear and quince trees grafted on Pyrus calleryana and Chaenomeles sinensis rootstocks
}

\author{
Evaldo Tadeu de Melo(1), Rafael Pio(1), Rodrigo Vieira Balbi(1), \\ Cassiana Alves Ferreira( ${ }^{(2)}$ and Fábio Akira Mori(2)
}

(1)Universidade Federal de Lavras (Ufla), Departamento de Agricultura, Caixa Postal 3.037, CEP 37200-000 Lavras, MG, Brazil. E-mail:
evaldo.melo@dag.ufla.br, rafaelpio@dag.ufla.br, balbilavras@yahoo.com.br (2)Ufla, Departamento de Ciências Florestais, Caixa
Postal 3.037, CEP 37200-000 Lavras, MG, Brazil. E-mail: cassianaaf@gmail.com, morif@dcf.ufla.br

Abstract - The objective of this work was to evaluate the graft growth and the anatomical characterization of pear (Pyrus communis x P. pyrifolia) and quince (Cydonia oblonga) cultivars grafted on Pyrus calleryana and Chaenomeles sinensis rootstocks. Sprouted graft percentages at 60 days and the length and diameter of the graft sproutings at 120 days were evaluated. Stem cuttings from the grafting region were performed in transversal and longitudinal sections, and the secondary xylem was separated for tissue comparison. The pear trees showed good development on P. calleryana rootstock, and the anatomical sections showed that the vascular tissues were connected, which did not occur when the trees were grafted on $C$. sinensis, in which the grafts sprouted, but did not develop, and the vascular tissues did not connect. The quince trees showed good development on both rootstocks due to the good connection of the vascular tissues. The connection of vascular tissues is essential for the success of grafting. The evaluated species did not differ significantly as to their secondary xylem tissues. The incompatibility found between the pear trees and the $C$. sinensis rootstocks is not anatomical.

Index terms: Cydonia oblonga, Pyrus communis x P. pyrifolia, intergeneric grafting, interspecific grafting, plant anatomy, vascular connection.

\section{Compatibilidade anatômica de pereiras e marmeleiros enxertados nos porta-enxertos Pyrus calleryana e Chaenomeles sinensis}

Resumo - O objetivo deste trabalho foi avaliar o crescimento dos enxertos e a caracterização anatômica de cultivares de pereira e marmeleiro enxertadas nos porta-enxertos Pyrus calleryana e Chaenomeles sinensis. Foram feitas avaliações quanto às percentagens dos enxertos brotados aos 60 dias e quanto ao comprimento e o diâmetro da brotação dos enxertos aos 120 dias. Cortaram-se porções caulinares da região da enxertia, em seções transversais e longitudinais, e o xilema secundário foi separado para comparação dos tecidos. As pereiras apresentaram bom desenvolvimento sobre o porta-enxerto P. calleryana, e os cortes anatômicos apresentaram tecidos vasculares conectados, o que não ocorreu quando as pereiras foram enxertadas em $C$. sinensis, em que os enxertos brotaram mas não se desenvolveram, e os tecidos vasculares não se conectaram. Os marmeleiros apresentaram bom desenvolvimento em ambos os porta-enxertos, em razão da boa conexão dos tecidos vasculares. A conexão dos tecidos vasculares é fundamental para o sucesso da enxertia. As espécies utilizadas não diferiram significativamente quanto a seus tecidos do xilema secundário. A incompatibilidade encontrada entre as pereiras e o porta-enxerto $C$. sinensis não é anatômica.

Termos para indexação: Cydonia oblonga, Pyrus communis x P. pyrifolia, enxertia intergenérica, enxertia interespecífica, anatomia de plantas, conexão vascular.

\section{Introduction}

The cultivation of pear trees in regions with a mild winter is possible due to hybrid cultivars from Pyrus communis $\mathrm{x}$ P. pyrifolia, known as rustic pears, which require less cold to overcome dormancy (Nogueira et al., 2016). In European cultures, pear trees are propagated mainly by grafting on quince trees (Cydonia oblonga) that allow dense planting. However, quince trees do not develop well under Brazilian tropical and subtropical conditions, since they tolerate neither high temperatures on the soil surface nor their cultivation in acidic soils, as most cultivars were selected under alkaline soil conditions in Europe (Seifert et al., 2009). 
The use of rootstocks of the genus Pyrus for commercial pear cultivars has the advantages both for adaptation to the subtropical climate and for resistance to fire blight (Erwinia amylovora). However, Pyrus rootstocks provide very vigorous crowns, which makes it difficult to conduct plants in high-density orchards (Bettiol Neto et al., 2014). Nonetheless, rootstocks of the Pyrus genus could be an option to provide vigor for quince cultivars, considering that some of them have a slow initial development in the early post-planting years, when propagated by cuttings or grafting (Bettiol Neto et al., 2011), and others have low-rooting capacity (Celant et al., 2010).

Currently, the quince cultivar 'Japonês' of Chaenomeles sinensis has been used as a rootstock for Cydonia quince. This cultivar shows a high number of seed per fruit, high-seed germination, and high rates of seedling emergence (Pio et al., 2008a), besides favoring good growth for most quince cultivars (Pio et al., 2008b). This rootstock could be also used for pear cultivars, in order to bypass the obstacles related to the limited use of quince trees from the genus Cydonia, and to promote the formation of high-density orchards in the Brazilian subtropical regions. However, until present, no study was found on the grafting of pear trees on this rootstock.

One way to assess the compatibility of grafting is through anatomical analyses (Pina et al., 2012) of graft growth evaluations. The success of grafting is directly related to the anatomical compatibility among the used tissues, whose connections should be continuous between the vascular cambia of graft and rootstock, mainly when they belong to taxonomically distant classes, such as the case of intergeneric grafting (Pio et al., 2008a). The proper regeneration and junction of conducting vessels are considered essential for the compatibility among different materials in this propagation technique. However, due to the numerous interactions that occur between the graft and rootstock during the grafting process, it is very difficult to determine incompatibility, which can be related to several factors (Pina et al., 2012).

The objective of this work was to evaluate the graft growth and the anatomical characterization of pear (Pyrus communis x P. pyrifolia) and quince (Cydonia oblonga) cultivars grafted on $P$. calleryana and Chaenomeles sinensis rootstocks.

\section{Materials and Methods}

Seed of the $P$. calleryana and $C$. sinensis rootstocks were extracted from ripe fruit collected in April. Then, seed were washed in running water, dried in the shade for 48 hours, and distributed on Petri dishes (90x15 mm) lined with moistened cotton, and subjected to cold stratification in BOD type camera at $4^{\circ} \mathrm{C}$, for 30 days, according to the methodology of Pio et al. (2008a). After this, seed were dispersed in polystyrene trays with 72 cells $\left(50 \mathrm{~cm}^{3}\right.$ each), filled with expanded vermiculite of medium particles as substrate.

After 60 days, the seedlings were transferred to 2-L plastic bags with substrate consisting of soil of a bank, sand, and organic compost, in equal proportions, added with $200 \mathrm{~g} \mathrm{~m}^{-3}$ single superphosphate fertilizer. The seedlings were kept in a screened nursery with $50 \%$ shading, and conducted with a single stem.

After 11 months from the transplant to the plastic bags, the grafting was performed, when seedlings of both rootstocks showed, on average, $7 \mathrm{~mm}$ diameter and $15 \mathrm{~cm}$ height. Branches from the pear hybrids 'Centenária', 'D'água', 'Cascatense', 'Red Bartlett', 'Packham's Triumph', 'Williams', 'Triunfo', 'Seleta', 'Tenra', 'Primorosa', and 'Le Conte' were collected. The quince cultivars 'Portugal' and 'Mendoza Inta-37' were collected at the time of winter pruning, held in June. Pear and quince plants of the different cultivars came from a six-year-old experimental cultivation, located in the fruit-growing sector of Universidade Federal de Lavras. The plants were periodically sprayed with pesticides in order to avoid phytosanitary problems. From these collected branches, grafts with approximately $10-\mathrm{cm}$ length and $7-\mathrm{mm}$ diameter were fragmented, for slot grafting onto the rootstocks. After grafting, the grafts were tied with plastic tapes and protected with a plastic bag measuring $15 \times 2 \mathrm{~cm}$, in order to form a humid chamber and avoid their dehydration. The plastic bags were removed 30 days after grafting, and the tied plastic tapes, at 60 days.

Two experiments were carried out. The first one in a completely randomized design, in a $2 \times 11$ factorial arrangement, with the two rootstocks considered as the first factor, and the pear cultivars as the second one, with five replicates, and ten grafts per plot. The second experiment was performed in a completely randomized design, in a $2 \times 2$ factorial arrangement, with two rootstocks as the first factor, and two quince 
cultivars as the second one, with five replicates, and ten grafts per plot.

In both experiments, the percentages of sprouted graft at 60 days after grafting were evaluated. After this evaluation, only one sprout per graft was selected for conduction in the vertical position. After another 60 days, the length and diameter at the base of the graft sprouts were evaluated. The data were subjected to the analysis of variance, and the averages were grouped by the Scott-Knott's test, at 5\% probability. The analyses were performed with the computer software Sisvar (Ferreira, 2011).

For the anatomical analysis of the tissues at the grafting point, at 120 days after grafting, stem cuttings of approximately $2 \mathrm{~cm}$ long were collected, exactly in the grafting region from all canopy/rootstock combinations, and fixed at $70 \%$ F.A.A. (formaldehyde, glacial acetic acid, and 70\% ethanol at 0.5: 0.5: $9 \mathrm{v} / \mathrm{v}$ ) for 48 hours, and subsequently stored in $70 \%$ ethanol.

For the slide preparation, the region where the best connection of the tissues occurred was determined, in order to perform the cuts. Cross-sections and longitudinal sections were performed at $14 \mu \mathrm{m}$ thickness, using a Jung SM 2000 sliding microtome (Leica Mikrosysteme Vertrieb GmbH Mikroskopie und Histologie, Wetzlar, Germany); the cross-section was made at the base of the graft wedge, and the longitudinal section was perpendicular to the wedge, laterally coinciding with the cambium region. Sections were clarified in sodium hypochlorite for $5 \mathrm{~min}$, washed threefold in distilled water for $30 \mathrm{~s}$ each, stained with safrablau at $1 \%$ for $1 \mathrm{~min}$, then washed again in distilled water for $30 \mathrm{~s}$ and, subsequently, dehydrated in $20 \%$ alcohol solution for $1 \mathrm{~min}$. Then, they were mounted on semipermanent slides with glycerinated gelatin, and sealed with colorless enamel. The photomicrographs were obtained with the aid of a Zeiss optical microscope (Carl Zeiss AG Corporate Headquarters, Oberkochen, Germany), with a coupled capture system.

To characterize the vessel elements, the component tissues of the secondary xylem were separated through a macerating solution of hydrogen peroxide and $1 \mathrm{~N}$ acetic acid, at 1:1 (v/v). The material was taken to the oven at $65^{\circ} \mathrm{C}$ for 24 hours, which is a sufficient time to dissolve cells. The temporary slides were prepared with glycerin, and the histological material was stained with safranine at $1 \%$. The partial descriptions of the secondary xylem of crown cultivars and rootstocks, and the quantitative data were obtained through the WinCell software (Regent Instruments, Inc., Ville de Québec, Canada), with the aid of a microscope coupled to the computer. The data were tabulated in the Excel software. A biometric description was made for the vessel elements, and for the ray parenchyma of the secondary xylem of pear trees, quince trees, and of $P$. calleryana, and $C$. sinensis rootstocks, with 30 measurements for length $(\mu \mathrm{m})$ and diameter $(\mu \mathrm{m})$ of the vessel elements, 30 measurements for height $(\mu \mathrm{m})$ and width $(\mu \mathrm{m})$ of the ray parenchyma, and 10 measurements for the frequencies $\left(\mathrm{n}^{\circ} \mathrm{mm}^{-2}\right)$ of vessel elements and ray parenchyma.

\section{Results and Discussion}

For the experiment conducted with the pear trees, there was no significant difference in the sprouting percentage among the cultivars, when the grafts were grafted on $P$. calleryana rootstock; a difference occurred only when grafting was performed on C. sinensis (Table 1). The least sproutings occurred in the cultivars 'Le Conte', 'Packham's Triumph', and 'D'agua' grafted on C. sinensis. Sprouting diameters of 'Tenra', 'Williams', 'Cascatense', 'Primorosa', 'Seleta', and 'Packham's Triumph' was not affected by the rootstock used. The highest diameters of sproutings occurred in 'Triunfo', 'Le Conte', and 'D'água', when grafted on $P$. calleryana, and in 'Centenária' and 'Red Bartlett' when grafted on $C$. sinensis. The sprouting length in 'D'água', 'Seleta', and 'Williams' were not affected by the rootstock used. However, the other cultivars showed a higher development when grafted on the $P$. calleryana rootstock, in which 'Triunfo' cultivar outstood with $26.67 \mathrm{~cm}$ average sprouting length (Table 1). However, when the pear cultivars were grafted on $C$. sinensis quince tree, the graft sprout growth was minimal. From the results of sprouting percentages, some success was expected in the combination of the pear cultivars with the $C$. sinensis rootstock, but the results showed incompatibility between graft and rootstock. Bianchi et al. (2004) reported an effect on graft sprouting growth of pear trees, related to the quince cultivars used as rootstocks. Moreover, the authors reported that development was superior to the ones reported in the present study, since they used quince trees from the species Cydonia 
oblonga. According to Giacobbo et al. (2007), the incompatibility between graft and rootstocks may be related to phytosanitary problems from plant materials. Nonetheless, it is believed that the lower development of pear trees grafted on quince trees may be related to poor tissue affinity when grafting pear trees on C. sinensis rootstock.

Souza et al. (2011) worked under hydroponic conditions with three pear cultivars grafted on $P$. calleryana rootstock, and obtained the same sprouting percentage and similar length to that obtained in the present study. Seifert et al. (2009) found high values with the $C$. sinensis rootstock, for 'Selecta' and 'Triunfo' cultivars $(26.4 \mathrm{~cm}$ and $19.4 \mathrm{~cm}$, respectively), with the use of interstocks from the genus Cydonia. The use of interstocks avoids the incompatibility between graft and rootstock, without reducing the yield, although it may decrease the plant size (Yonemoto et al., 2004).

For the cross-sections, a connection was observed in the vascular elements between pear trees and P. calleryana rootstock (Figures $1 \mathrm{~A}$ and $1 \mathrm{~B}$ ). However, such connection did not occur when pear trees were grafted onto $C$. sinensis rootstock (Figures $1 \mathrm{C}$ and $1 \mathrm{D})$, in which there was formation of a large mass of callus (undifferentiated parenchyma), without connection of the vascular tissues. It is possible to observe that this mass of callus originates exclusively from the portion of the grafts, and no material has been developed from the rootstock (Figures $1 \mathrm{C}$ and $1 \mathrm{D})$. It is also possible to observe that there was no graft growth in pear trees grafted on $C$. sinensis rootstock, due to the absence of the rings from the growth layers. However, these rings could be seen in the portion of the graft and the rootstock when pear trees were grafted onto $P$. calleryana rootstock (Figures $1 \mathrm{~A}$ and $1 \mathrm{~B}$ ).

Probably, sprouts of pear grafted on $C$. sinensis occurred due to the reserves contained in the graft (Figures $1 \mathrm{C}$ and $1 \mathrm{D}$ ); and, according to Moore (1986), callus formation does not represent a compatibility symptom because it is resulted only from a cytoplasmic reorganization. The adequate regeneration and junction of conducting vessels is essential to prove the compatibility of different materials with this propagation technique (Pina et al., 2012).

The longitudinal sections between pear trees and $P$. calleryana rootstock (Figures $2 \mathrm{~A}$ and $2 \mathrm{~B}$ ) show that the vascular tissues were connected. In contrast, when pear trees were grafted onto $C$. sinensis rootstock, only a large mass of callus (undifferentiated parenchyma) was observed as filling the empty space at the connection point (Figures $2 \mathrm{C}$ and $2 \mathrm{D}$ ). This confirms what was observed in the cuts in the cross-sections. 'Triunfo' pear grafted on $P$. calleryana rootstock showed the highest development for sprout length (Table 1), and the better connection of vascular tissues (Figure 2 A). However, 'Williams' showed a low development of sprout length, when grafted on $P$. calleryana, but the connection of vascular tissues was not as complete as 'Triunfo', and some space was observed as filled by undifferentiated parenchyma (Figure 2 B). The

Table 1. Graft sprouts at 60 days, and diameter and length at 120 days after grafting of pear (Pyrus communis x P. pyrifolia) cultivars grafted on Pyrus calleryana and Chaenomeles sinensis rootstocks. ${ }^{(1)}$

\begin{tabular}{|c|c|c|c|c|c|c|}
\hline \multirow[t]{2}{*}{ Cultivar } & \multicolumn{2}{|c|}{ Shoot (\%) } & \multicolumn{2}{|c|}{ Diameter $(\mathrm{mm})$} & \multicolumn{2}{|c|}{ Length $(\mathrm{cm})$} \\
\hline & Pyrus calleryana & Chaenomele sinensis & Pyrus calleryana & Chaenomele sinensis & Pyrus calleryana & Chaenomeles sinensis \\
\hline Triunfo & $100.0 \mathrm{Aa}$ & $87.5 \mathrm{Aa}$ & $5.2 \mathrm{Aa}$ & $3.9 \mathrm{Bb}$ & $26.6 \mathrm{Aa}$ & $0.7 \mathrm{Ba}$ \\
\hline Cascatense & $91.8 \mathrm{Aa}$ & $92.5 \mathrm{Aa}$ & $4.5 \mathrm{Aa}$ & 4.7Aa & $17.1 \mathrm{Ab}$ & $1.6 \mathrm{Ba}$ \\
\hline Le Conte & $100.0 \mathrm{Aa}$ & $27.5 \mathrm{Bb}$ & 4.7Aa & $2.5 \mathrm{Bc}$ & $16.7 \mathrm{Ab}$ & $0.3 \mathrm{Ba}$ \\
\hline Tenra & $100.0 \mathrm{Aa}$ & $87.5 \mathrm{Aa}$ & 4.7Aa & $5.0 \mathrm{Aa}$ & $14.1 \mathrm{Ab}$ & $1.3 \mathrm{Ba}$ \\
\hline Primorosa & $100.0 \mathrm{Aa}$ & $90.0 \mathrm{Aa}$ & $4.5 \mathrm{Aa}$ & $4.8 \mathrm{Aa}$ & $11.4 \mathrm{Ac}$ & $1.8 \mathrm{Ba}$ \\
\hline Packham's Triumph & $91.8 \mathrm{Aa}$ & $65.0 \mathrm{Bb}$ & $3.9 \mathrm{Ab}$ & $4.4 \mathrm{Ab}$ & 9.1Ac & $0.9 \mathrm{Ba}$ \\
\hline Red Bartlett & $83.5 \mathrm{Aa}$ & $77.5 \mathrm{Ab}$ & $4.0 \mathrm{Bb}$ & 4.7Aa & $7.0 \mathrm{Ac}$ & $0.7 \mathrm{Ba}$ \\
\hline Centenária & $91.8 \mathrm{Aa}$ & $95.0 \mathrm{Aa}$ & $4.3 \mathrm{Bb}$ & $5.4 \mathrm{Aa}$ & $6.7 \mathrm{Ac}$ & $1.0 \mathrm{Ba}$ \\
\hline D’agua & $100.0 \mathrm{Aa}$ & $80.0 \mathrm{Bb}$ & $4.0 \mathrm{Ab}$ & $3.0 \mathrm{Bc}$ & 5.9Ac & $0.9 \mathrm{Aa}$ \\
\hline Seleta & $91.8 \mathrm{Aa}$ & $90.0 \mathrm{Aa}$ & $4.3 \mathrm{Ab}$ & 4.7Aa & $5.6 \mathrm{Ac}$ & $2.7 \mathrm{Aa}$ \\
\hline$\underline{\text { Williams }}$ & $91.8 \mathrm{Aa}$ & $77.5 \mathrm{Ab}$ & 4.6Aa & 5.1Aa & $5.2 \mathrm{Ac}$ & 1.7Aa \\
\hline $\mathrm{CV}(\%)$ & \multicolumn{2}{|r|}{14.46} & \multicolumn{2}{|r|}{9.81} & \multicolumn{2}{|r|}{57.67} \\
\hline
\end{tabular}

${ }^{(1)}$ Means followed by equal letters, uppercase in the rows and lowercase in the columns, do not differ by the Scott-Knott's test, at 5\% probability. 
external symptoms of this connection are not evident, and it may take several years to identify them (Pina \& Errea, 2008); furthermore, in more advanced stages, a root system depletion occurs due to poor translocation of photoassimilates at the union point (Zarrouk et al., 2010).

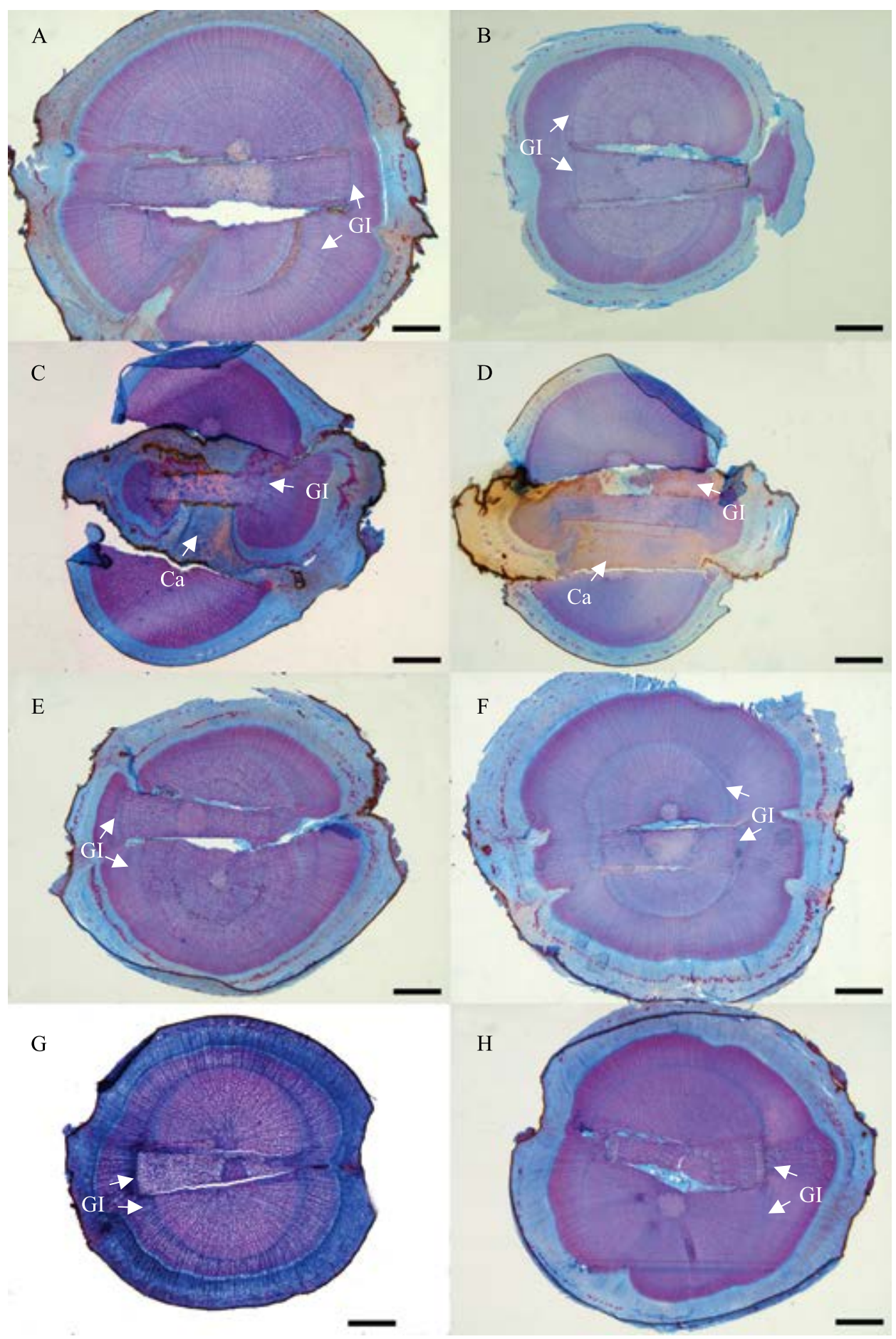

Figure 1. Cross-sections in the grafting region of pear and quince cultivars on Pyrus calleryana and Chaenomeles sinensis rootstocks: A, 'Triunfo'/Pyrus calleryana; B, 'Williams'/Pyrus calleryana; C, 'Triunfo'/Chaenomeles sinensis; D, 'Williams/ Chaenomeles sinensis; E, 'Portugal'/Pyrus calleryana; F, 'Mendoza Inta-37'/Pyrus calleryana; G, 'Portugal'/Chaenomeles sinensis; H, 'Mendoza Inta-37'/Chaenomeles sinensis. GL, growth layer; and Ca, callus. Bar $=2 \mathrm{~mm}$. 
Machado et al. (2015) compared the trunk diameter with the continuity of the xylem vessels in the grafting region of six pear cultivars, on two quince rootstocks of the genus Cydonia, and observed that the greatest vigor is associated with the compatibility in the grafting region, with a continuous flow between the conducting vessels of the graft and the rootstock, which allowed the passage of the staining in the vascular bundles. Giacobbo et al. (2007) evaluated the compatibility degree between quince of genus Cydonia and the pears 'Cascatense', 'Carrick' and 'Seleta', and observed that although 'Cascatense' showed a higher crown volume

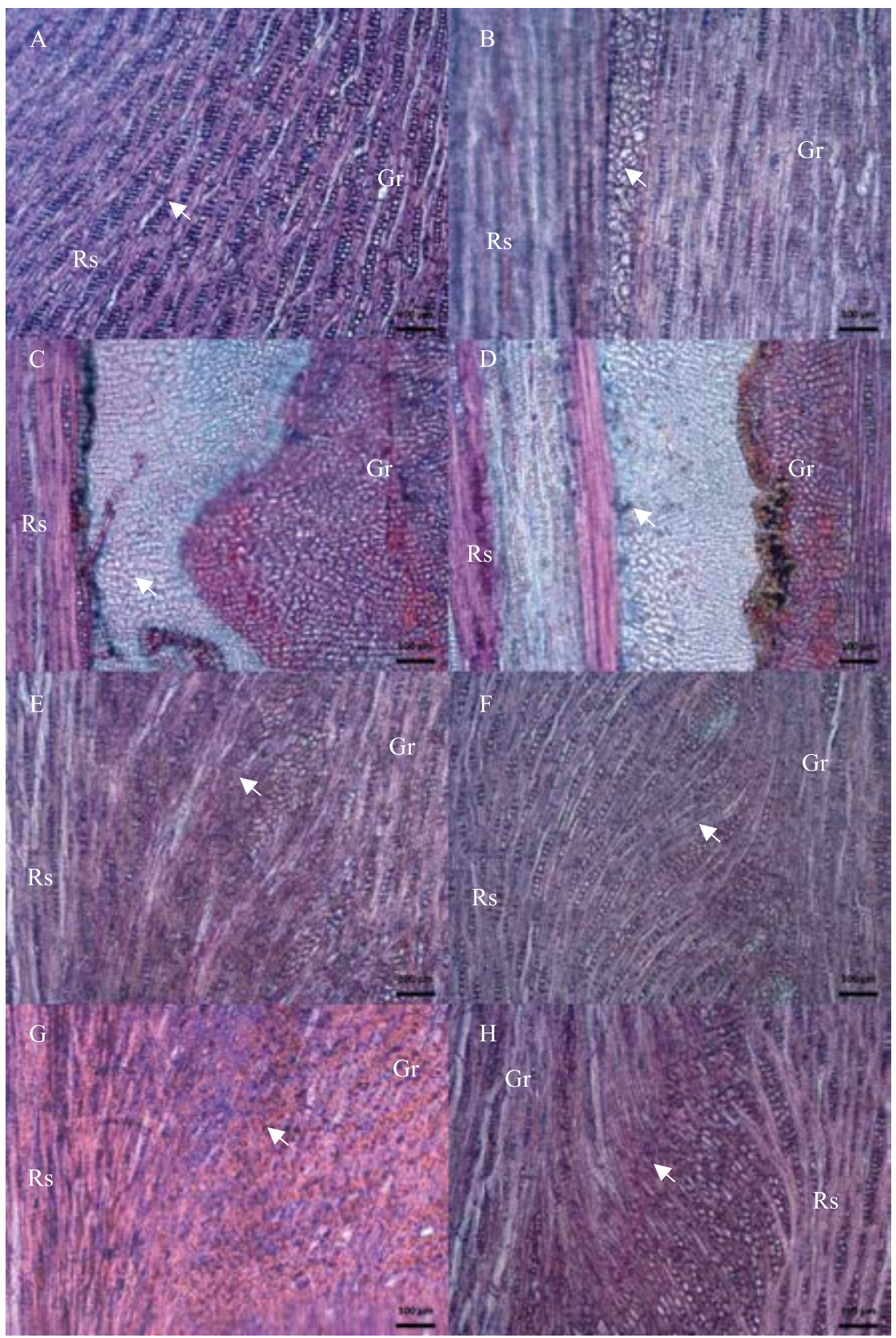

Figure 2. Longitudinal sections in the grafting region of pear and quince cultivars on Pyrus calleryana and Chaenomeles sinensis rootstocks: A, 'Triunfo'/Pyrus calleryana; B, 'Williams'/Pyrus calleryana; C, 'Triunfo'/Chaenomeles sinensis; D, 'Williams'/Chaenomeles sinensis; E, 'Portugal'/Pyrus calleryana; F, 'Mendoza Inta-37'/Pyrus calleryana; G, 'Portugal'/ Chaenomeles sinensis; H, 'Mendoza Inta-37'/Chaenomeles sinensis. Rs, rootstock; and Gr, graft. The arrows indicate the region of union between graft and rootstock. Bar $=100 \mu \mathrm{m}$. 
than the other cultivars, there was an incompatibility in its combination with quince due to a large difference in the trunk diameter between crown and rootstock.

For the experiment conducted with quince cultivars used as crown, no significant difference was observed between the crown cultivars (Table 2), except for 'Mendoza Inta-37', which showed the lowest-sprouting rate when grafted on the rootstock $P$. Calleryana. The values found in the present study were similar to those reported by Celant et al. (2010), who tested cold-stored buddings for different periods, and compared graft budding and cleft grafting of 'Portugal', 'Mendoza Inta37', 'Japonês', 'Provence', and 'Smyrna' cultivars on the rootstock $C$. Sinensis.

For sprout diameter and length, there was no significant difference between quince cultivars grafted on $P$. calleryana and $C$. sinensis. The cross-section cuts evidenced that the vascular tissues were connected between graft and rootstock in all treatments (Figures 1 E, $1 \mathrm{~F}, 1 \mathrm{G}$, and $1 \mathrm{H}$ ). In the longitudinal sections, a good connection of vascular tissues was observed in all treatments, in addition to a large number of ray parenchyma in this region (Figures $2 \mathrm{E}, 2 \mathrm{~F}, 2 \mathrm{G}$, and $2 \mathrm{H})$.

'Portugal' quince grafted on P. calleryana showed union of the vascular tissues only on one side of the graft. Possibly, at the time of grafting the fit was not perfect on this plant, and the cambium regions of the graft and the rootstock did not coincide (Figure $1 \mathrm{E}$ ), which can be attributed to the grafting type (cleft grafting). Castro et al. (2009) commented that it is necessary a perfect junction between graft and rootstock in the cambium region for the establishment of grafting. The growth layer rings also evidenced that diameters of the rootstock and the graft developed, which occurs only when there is grafting success. Sajo \& Castro (2006) reported that when cambium activity begins, it produces periclinal divisions from the secondary xylem to the interior, and phloem to the periphery and, due to anticlinal divisions, the graft follows the thickning of the stem.

Pina \& Errea (2009) found that insufficient plasmodesmal coupling, at an early stage of graft development, can lead to problematic vascular connections, with tissue discontinuity and phloem degeneration in the union area, resulting in graft incompatibility. Pina et al. (2012), in a study on different combinations of Prunus, showed that callus proliferation and adherence occur in both compatible and incompatible combinations one week after grafting. However, the formation of the new cambium, derived from callus tissue, appears to be delayed in interspecific grafts in comparison to intraspecific ones. This report reinforces the hypothesis that callus cells are playing a central role in the interaction between graft and rootstock, and that final rejection is already predetermined in the initial stages of graft formation.

In the comparison of the component elements of the secondary xylem, no significant differences were found among the species used in the experiment (Table 3). The vessel elements were long, with appendages present at both ends, or occurring in only one end (Figure 3), with simple perforation plates, predominantly solitary with small pits. Paratracheal and scanty axial parenchyma was observed, and the porosity was diffuse in a diagonal arrangement. Fibers were libriform, and the radial parenchyma was composed of mostly uniseriate rays (only one cell wide), and also with multiseriate rays (with two or three cells of width), with the presence of crystals in fibrous chambers, and with wall-thickening of vessel elements and fibers in spiral form. By the comparison of the component elements of the secondary xylem, the causes of low-growth of pear tree cultivars grafted on $C$. sinensis may be linked to enzymes (Pereira et al., 2015).

Table 2. Graft sprouts at 60 days, diameter and length at 120 days after grafting of quince (Cydonia oblonga) tree cultivars grafted on Pyrus calleryana and Chaenomeles sinensis rootstocks ${ }^{(1)}$.

\begin{tabular}{|c|c|c|c|c|c|c|}
\hline \multirow[t]{2}{*}{ Cultivar } & \multicolumn{2}{|c|}{ Shoot (\%) } & \multicolumn{2}{|c|}{ Diameter $(\mathrm{mm})$} & \multicolumn{2}{|c|}{ Length (cm) } \\
\hline & Pyrus calleryana & Chaenomeles sinensis & Pyrus calleryana & Chaenomeles sinensis & Pyrus calleryana & Chaenomeles sinensis \\
\hline Portugal & $60.5 \mathrm{Aa}$ & 74.7Aa & 3.9Aa & 4.1Aa & $26.2 \mathrm{Aa}$ & 31.7Aa \\
\hline Mendoza Inta-37 & $57.0 \mathrm{Ba}$ & $78.5 \mathrm{Aa}$ & 3.9Aa & 4.3Aa & $30.1 \mathrm{Aa}$ & $36.1 \mathrm{Aa}$ \\
\hline $\mathrm{CV}(\%)$ & \multicolumn{2}{|c|}{15.52} & \multicolumn{2}{|c|}{12.22} & \multicolumn{2}{|c|}{17.95} \\
\hline
\end{tabular}

${ }^{(1)}$ Means followed by equal letters, uppercase in the rows and lowercase in the columns, do not differ by the Scott-Knott' test, at $5 \%$ probability. 
Table 3. Biometric description of vessel elements and ray parenchyma of the secondary xylem of pear (Pyrus communis $\mathrm{x}$ P. pyrifolia) trees, quince (Cydonia oblonga) trees, and P. calleryana and C. sinensis rootstockss.

\begin{tabular}{|c|c|c|c|c|c|c|c|c|c|c|c|c|}
\hline \multirow[t]{3}{*}{ Genotype } & \multicolumn{6}{|c|}{ Vessel elements $^{(1)}$} & \multicolumn{6}{|c|}{ Ray parenchyma ${ }^{(2)}$} \\
\hline & \multicolumn{2}{|c|}{$\begin{array}{l}\text { Length } \\
(\mu \mathrm{m})\end{array}$} & \multicolumn{2}{|c|}{$\begin{array}{l}\text { Diameter } \\
(\mu \mathrm{m})\end{array}$} & \multicolumn{2}{|c|}{$\begin{array}{c}\text { Frequency } \\
\left(\text { number } \mathrm{mm}^{-2}\right)\end{array}$} & \multicolumn{2}{|c|}{$\begin{array}{l}\text { Height } \\
(\mu \mathrm{m})\end{array}$} & \multicolumn{2}{|c|}{$\begin{array}{l}\text { Width } \\
(\mu \mathrm{m})\end{array}$} & \multicolumn{2}{|c|}{$\begin{array}{c}\text { Frequency } \\
\left(\text { number } \mathrm{mm}^{-1}\right)\end{array}$} \\
\hline & Mean & SD & Mean & SD & Mean & SD & Mean & SD & Mean & $\mathrm{SD}$ & Mean & $\mathrm{SD}$ \\
\hline Pyrus calleryana & 303.4 & 87.8 & 13.1 & 3.3 & 278.0 & 77.5 & 193.1 & 67.3 & 13.2 & 2.9 & 13.5 & 1.7 \\
\hline Chaenomeles sinensis & 308.2 & 97.5 & 22.1 & 5.4 & 165.0 & 13.6 & 276.5 & 100.7 & 17.5 & 5.7 & 15.5 & 2.0 \\
\hline Triunfo & 280.6 & 87.1 & 18.5 & 4.2 & 487.0 & 45.5 & 217.6 & 96.5 & 15.2 & 4.6 & 18.0 & 4.2 \\
\hline Cascatense & 295.7 & 78.6 & 18.4 & 4.5 & 435.0 & 139.9 & 213.5 & 66.1 & 19.3 & 6.9 & 20.7 & 3.2 \\
\hline Leconte & 345.4 & 118.8 & 18.5 & 3.3 & 413.0 & 35.5 & 217.6 & 76.4 & 27.6 & 7.5 & 16.7 & 4.7 \\
\hline Tenra & 320.1 & 102.5 & 18.7 & 3.8 & 343.0 & 53.7 & 219.2 & 97.7 & 20.3 & 4.5 & 20.3 & 4.7 \\
\hline Primorosa & 272.1 & 86.3 & 19.2 & 3.4 & 298.0 & 56.8 & 212.7 & 84.6 & 24.0 & 7.3 & 17.0 & 3.0 \\
\hline Packham's Triumph & 328.1 & 119.3 & 17.7 & 4.1 & 316.0 & 102.2 & 241.6 & 109.6 & 17.3 & 4.9 & 16.0 & 4.0 \\
\hline Red Bartlett & 313.4 & 77.4 & 24.2 & 4.8 & 307.0 & 32.6 & 226.2 & 87.2 & 17.9 & 5.9 & 21.5 & 4.2 \\
\hline Centenária & 322.7 & 99.3 & 18.6 & 5.4 & 365.0 & 92.9 & 265.1 & 95.8 & 15.5 & 3.5 & 15.2 & 3.5 \\
\hline D'agua & 329.6 & 103.9 & 20.7 & 4.8 & 359.0 & 20.7 & 178.3 & 83.0 & 13.9 & 3.6 & 19.2 & 2.2 \\
\hline Seleta & 300.7 & 71.0 & 18.2 & 4.1 & 316.0 & 27.5 & 211.1 & 74.2 & 24.1 & 7.0 & 17.0 & 4.0 \\
\hline Williams & 306.1 & 79.4 & 18.9 & 4.5 & 392.0 & 92.8 & 267.4 & 82.2 & 18.5 & 7.3 & 15.5 & 2.2 \\
\hline Portugal & 215.7 & 83.9 & 22.0 & 4.6 & 328.0 & 23.6 & 227.2 & 87.3 & 12.5 & 3.2 & 13.7 & 2.5 \\
\hline Mendonza Inta-37 & 286.2 & 110.1 & 20.5 & 5.5 & 281.0 & 35.0 & 199.5 & 60.6 & 21.1 & 5.7 & 17.0 & 3.7 \\
\hline
\end{tabular}

${ }^{(1)}$ Thirty measurements for length and diameter, and ten for frequency. ${ }^{(2)}$ Thirty measurements for height and width, and ten for frequency. M

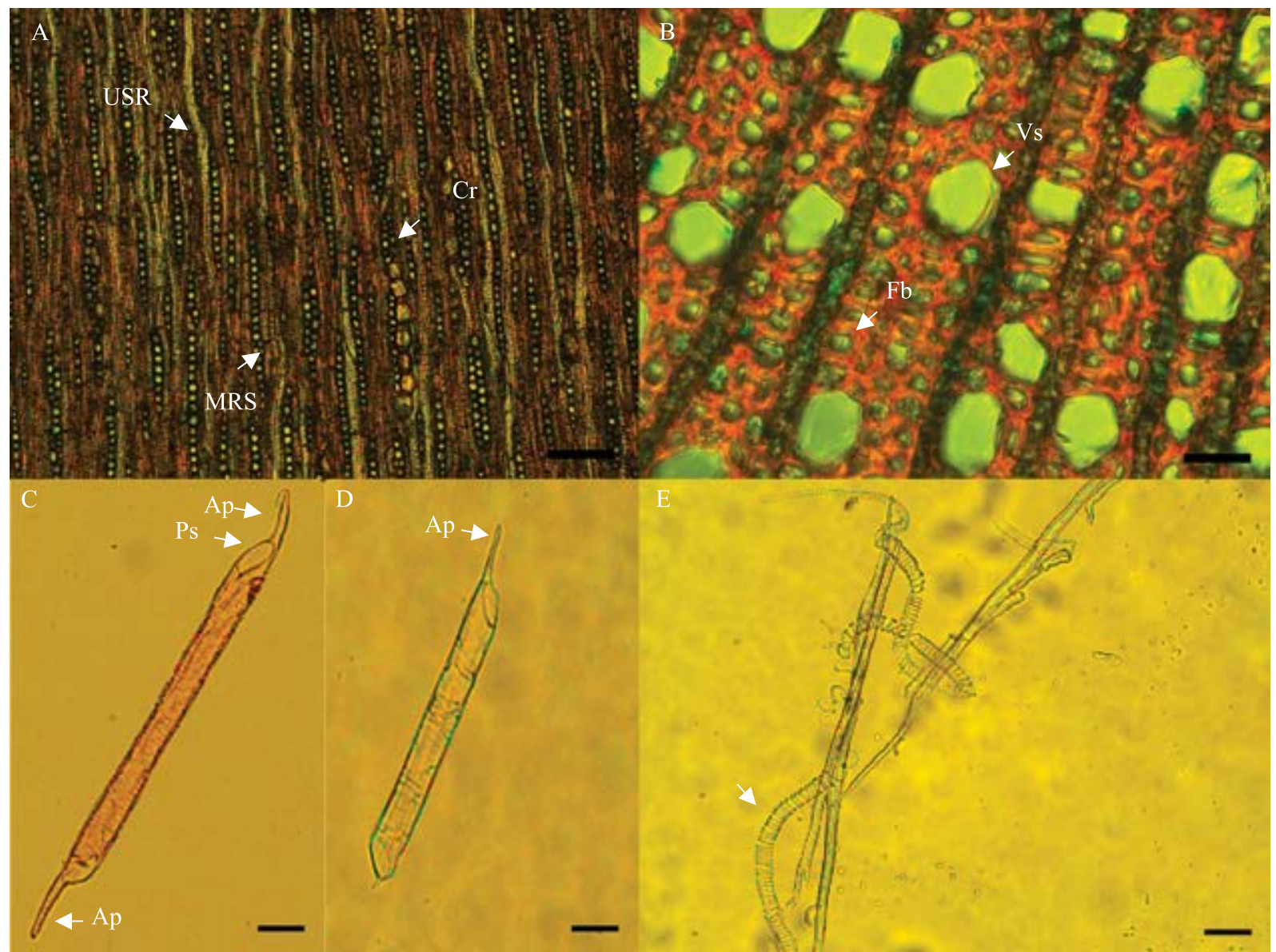

Figure 3. A, tangential, longitudinal section; $B$, cross section; $\mathrm{C}$ and $\mathrm{D}$, xylem vessel element; and $\mathrm{E}$, spiral thickening of vessel wall in the grafting region. USR, uniseriate rays; MRS, multiseriate rays; $\mathrm{Cr}$, crystals; Vs, vessels; Fb, fibers; and Ap, appendix. Bar $\mathrm{A}=100 \mu \mathrm{m}, \mathrm{B}=30 \mu \mathrm{m}, \mathrm{C}$ and $\mathrm{D}=20 \mu \mathrm{m}$, and $\mathrm{E}=40 \mu \mathrm{m}$. 
Gulen et al. (2002) evaluated the correlation of peroxidase isoenzyme profile among pears grafted on Cydonia, and found similarity among compatible combinations, which did not occur in the incompatible combinations, indicating that these could show an abnormal lignification at the grafting point, which would be the cause of their incompatibility. According to Santamour Jr. (1992), in order to obtain plants without compatibility problems, and with a functional vascular system at the graft union, the activities of the peroxidase enzyme should be similar, both in the graft and in the rootstock, so that the same cell restructuring and production of related lignins can occur.

For Nocito (2010), the cyanogenic glycosides (amygdalin and prunasin) are also associated to the incompatibility problem in grafting. The accumulation of cyanide released by the hydrolysis of these compounds at the graft union can cause necrosis to cambium cells and vascular discontinuity. According to Moore (1986), cyanide released at the graft union causes damage to the grafting activity, and cell necrosis at the graft interface, affecting the vascular system and hampering the sap translocation.

\section{Conclusions}

1. Graft sprouting does not indicate success in the intergeneric grafting.

2. The connection of vascular tissues is essential for the success of intergeneric grafting; therefore, the greater the connection of vascular tissues, the greater the graft development.

3. The evaluated pear cultivars are incompatible with Chaenomeles sinensis rootstock, and compatible with Pyrus calleryana rootstock; the quince cultivars show compatibility with both rootstocks.

4. The evaluated species show no significant differences in their vessel elements and in their ray parenchyma of the secondary xylem.

\section{References}

BETTIOL NETO, J.E.; CHAGAS, E.A.; SANCHES J.; PIO, R.; ANTONIALI, S.; CIA, P. Produção e qualidade pós-colheita de cultivares de pereira nas condições subtropicais da região leste paulista. Ciência Rural, v.44, p.1740-1746, 2014. DOI: 10.1590/0103-8478cr20131574.

BETTIOL NETO, J.E.; PIO, R.; SANCHES, J.; CHAGAS, E.A.; CIA, P.; CHAGAS, P.C.; ANTONIALI, S. Produção e atributos de qualidade de cultivares de marmeleiro na região leste paulista. Revista Brasileira de Fruticultura, v.33, p.1035-1042, 2011. DOI: 10.1590/S0100-29452011000300042.

BIANCHI, V.J.; VICENZI, M.; FACHINELLO, J.C. Percentagem de sobrevivência e resposta de crescimento de mudas de quatro cultivares de pereira enxertadas sobre diferentes cultivares de marmeleiro. Revista Brasileira de Agrociência, v.10, p.363-365, 2004. DOI: 10.18539/CAST.V10I3.973.

CASTRO, E.M. de; PEREIRA, F.J.; PAIVA, R. Caule. In: CASTRO, E.M. de; PEREIRA, F.J.; PAIVA, R. Histologia vegetal: estrutura e função de órgãos vegetativos. Lavras: Ed. da UFLA, 2009. p.150-173.

CELANT, V.M.; PIO, R.; CHAGAS, E.A.; ALVARENGA, A.A.; DALASTRA, I.M.; CAMPAGNOLO, M.A. Armazenamento a frio de ramos porta-borbulhas e métodos de enxertia de cultivares de marmeleiro. Ciência Rural, v.40, p.20-24, 2010. DOI: 10.1590/ S0103-84782009005000223.

FERREIRA, D.F. Sisvar: a computer statistical analysis system. Ciência e Agrotecnologia, v.35, p.1039-1042, 2011. DOI: 10.1590/ S1413-70542011000600001.

GIACOBBO, C.L.; FACHINELLO, J.C.; PICOLOTTO, L. Compatibilidade entre o marmeleiro porta-enxerto cv. 'EMC' e cultivares de pereira. Scientia Agraria, v.8, p.33-37, 2007. DOI: 10.5380/rsa.v8i1.8339.

GULEN, H.; ARORA, R.; KUDEN, A.; KREBS, S.L.; POSTMAN, J. Peroxidase isozyme profiles in compatible and incompatible pear-quince graft combinations. Journal of the American Society for Horticultural Science, v.127, p.152-157, 2002.

MACHADO, B.D.; MAGRO, M.; RUFATO, L.; BOGO, A.; KREZTSCHMAR, A.A.; SIMÕES, F. Compatibilidade fenotípica entre cultivares de pereiras europeias e porta-enxertos de marmeleiro. Ciência Rural, v.45, p.1551-1556, 2015. DOI: 10.1590/0103-8478cr20141128.

MOORE, R. Graft incompatibility between pear and quince: the influence of metabolites of Cydonia oblonga on suspension cultures of Pyrus communis. American Journal of Botany, v.73, p.1-4, 1986. DOI: $10.2307 / 2444270$.

NOCITO, F.F.; ESPEN, L.; FEDELI, C.; LANCILLI, C.; MUSACCHI, S.; SERRA, S.; SANSAVINI, S.; COCUCCI, M.; SACCHI, G.A. Oxidative stress and senescence-like status of pear calli co-cultured on suspensions of incompatible quince microcalli. Tree Physiology, v.30, p.450-458, 2010. DOI: 10.1093/ treephys/tpq006

NOGUEIRA, P.V.; COUTINHO, G.; PIO, R.; SILVA, D.F. da; ZAMBON, C.R. Establishment of growth medium and quantification of pollen grains and germination of pear tree cultivars. Revista Ciência Agronômica, v.47, p.380-386, 2016. DOI: $10.5935 / 1806-6690.20160045$.

PEREIRA, I. dos S.; PEREIRA, J.F.M.; CAMPOS, A.D.; PETRI, J.L.; COUTO, M. Glicosídeos cianogênicos e compatibilidade de enxertia em pereiras asiáticas enxertadas sobre Pyrus calleryana e P. betulifolia. Pesquisa Agropecuária Brasileira, v.50, p.854859, 2015. DOI: 10.1590/S0100-204X2015000900015. 
PINA, A.; ERREA, P. Differential induction of phenylalanine ammonia-lyase gene expression in response to in vitro callus unions of Prunus spp. Journal of Plant Physiology, v.165, p.705714, 2008. DOI: 10.1016/j.jplph.2007.05.015.

PINA, A.; ERREA, P. Morphological and histochemical features of compatible and incompatible stem unions. Acta Horticulturae, v.814, p.453-456, 2009. DOI: 10.17660/ActaHortic.2009.814.77.

PINA, A.; ERREA, P.; MARTENS, H.J. Graft union formation and cell-to-cell communication via plasmodesmata in compatible and incompatible stem unions of Prunus spp. Scientia Horticulturae, v.143, p.144-150, 2012. DOI: 10.1016/j.scienta.2012.06.017.

PIO, R.; CHAGAS, E.A.; BARBOSA, W.; SIGNORINI, G.; ALVARENGA, A.A.; ABRAHÃO, E.; ENTELMANN, F.A. Métodos de enxertia por garfagem de cultivares de marmeleiro no porta-enxerto 'Japonês'. Revista Brasileira de Fruticultura, v.30, p.267-270, 2008a. DOI: 10.1590/S0100-29452008000100050.

PIO, R.; CHAGAS, E.A.; BARBOSA, W.; SIGNORINI, G.; ENTELMANN, F.A.; FIORAVANÇO, J.C.; FACHINELLO, J.C.; BIANCHI, V.J. Desenvolvimento de 31 cultivares de marmeleiro enxertadas no porta-enxerto 'Japonês'. Revista Brasileira de Fruticultura, v.30, p.466-470, 2008b. DOI: 10.1590/S010029452008000200034.

SAJO, M. das G.; CASTRO, N.M. de. Caule. In: APPEZATTO, D.A.; GLÓRIA, B.; CARMELO-GUERREIRO, S.M. (Ed.).
Anatomia vegetal. 2.ed. rev. e atual. Viçosa: Ed. da UFV, 2006. p.283-302.

SANTAMOUR JR., F.S. Predicting graft incompatibility in woody plants. Proceedings of the International Plant Propagator's Society, v.42, p.131-134, 1992.

SEIFERT, K.E.; PIO, R.; CELANT, V.M.; CHAGAS, E.A. Mudas de pera produzidas por dupla enxertia em marmeleiro utilizando o porta-enxerto 'Japonês'. Pesquisa Agropecuária Brasileira, v.44, p.1631-1635, 2009. DOI: 10.1590/S0100204X2009001200010.

SOUZA, A. das G. de; CHALFUN, N.N.J.; FAQUIN, V.; SOUZA, A.A. de. Production of pear trees grafted under hydroponic conditions. Scientia Agraria, v.12, p.266-268, 2011. DOI: 10.5380/rsa.v12i1.33696.

YONEMOTO, Y.; MATSUMOTO, K.; FURUKAWA, T.; ASAKAWA, M.; OKUDA, H.; TAKAHARA, T. Effects of rootstock and crop load on sap flow rate in branches of 'Shirakawa Satsuma' mandarin (Citrus unshiu Marc.). Scientia Horticulturae, v.102, p.295-300, 2004. DOI: 10.1016/j.scienta.2004.02.005.

ZARROUK, O.; TESTILLANO, P.S.; RISUEÑO, M.C.; MORENO, M.A.; GOGORCENA, Y. Changes in cell/tissue organization and peroxidase activity as markers for early detection of graft incompatibility in peach/plum combinations. Journal of the American Society for Horticultural Science, v.135, p.9-17, 2010.

Received on May 19, 2016 and accepted on December 28, 2016 